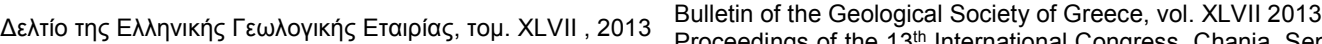

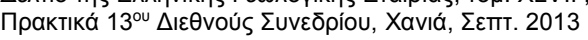
2013

\title{
MOLECULAR, CHEMICAL AND MORPHOLOGICAL EVIDENCE FOR HEMATITE BIOGENICITY AT THE QUATERNARY CAPE VANI MN-(BA-FE) DEPOSIT, MILOS, GREECE
}

\author{
Kilias S.P. ${ }^{1}$, Chatzitheodoridis E. ${ }^{2}$ and Lyon I. ${ }^{3}$ \\ ${ }^{1}$ National and Kapodistrian University of Athens, Faculty of Geology and Geoenvironment, \\ Department of Economic Geology-Geochemistry, kilias@geol.uoa.gr \\ ${ }^{2}$ National Technical University of Athens, School of Metallurgical and Mining Engineering, \\ Department of Geological Sciences, eliasch@metal.ntua.gr. \\ ${ }^{3}$ The University of Manchester, School of Earth, Atmospheric and Environmental Sciences \\ M139PL, Manchester, UK.
}

\begin{abstract}
Many aspects of the biotic or abiotic origin of iron-rich sedimentary rocks consisting mainly of hematite, an important indicator for exobiology, remain unresolved. Here, we use combined optical microscopy, scanning electron microscopy and energy dispersive X-ray spectrometry (SEM-EDS), Raman spectroscopy and time-of-flight secondary ion mass spectrometry (TOF-SIMS), to image the spatial distribution, and determine the composition, of potential biogenic markers (microbial microfossils, trace elements, organic ion species) in hematitemicrostromatolites and oncolite-like microstructures. These structures are identified in iron-rich material cementing a Quaternary fossil-beach conglomerate deposit in the Cape Vani area, NW Milos Island, Greece. The combined detection of morphological, chemical, and molecular organic-ion, biomarkers closely associated with possible hematite microfossils within microstromatolite laminae, strongly supports microbial mediation for their formation, and indicates that hematitic microlamination may be used as a biosignature for Fe-rich biomats on Earth and for their detection in extra-terrestrial materials. The Cape Vani hematitemicrostromatolites may contribute to growing our understanding of the function of microorganisms in the genesis of modern and ancient Fe deposits.
\end{abstract}

Key words: TOF-SIMS, microfossils, organic biomarkers, microstromatolites.

\section{Пєрí $\eta \psi \eta$}

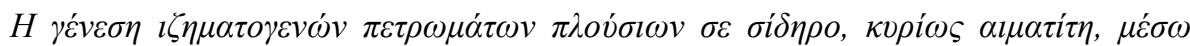

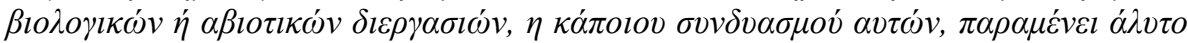

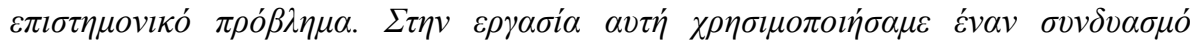

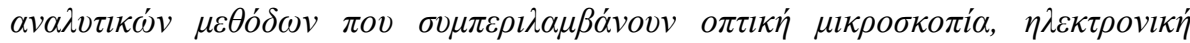

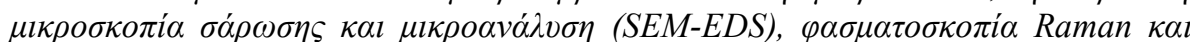

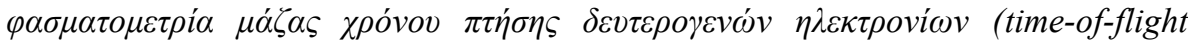

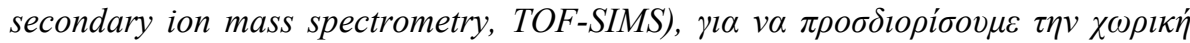

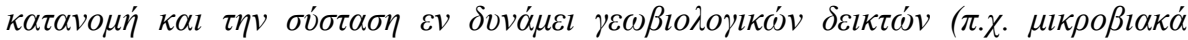

XLVII. No $2-834$ 


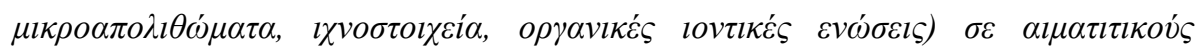

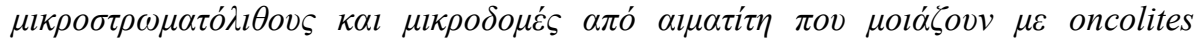

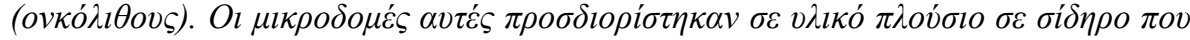

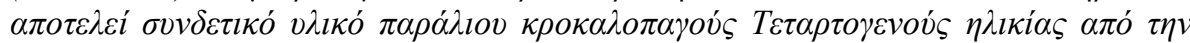

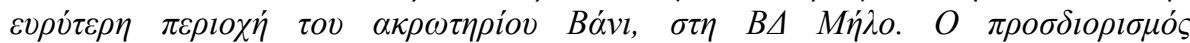

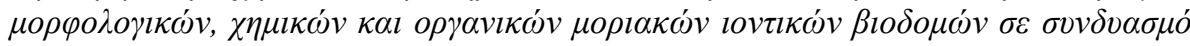

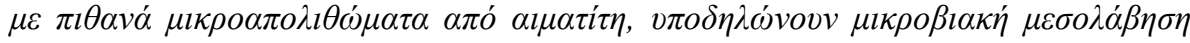

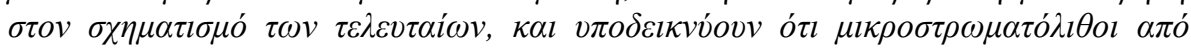

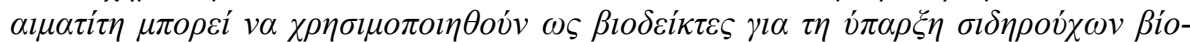

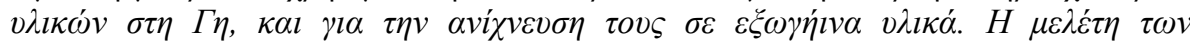

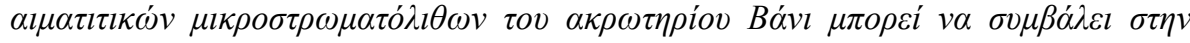

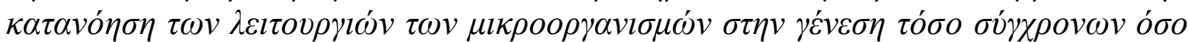

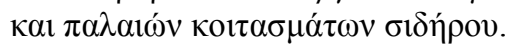

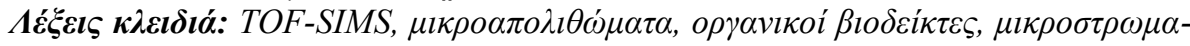
$\tau o ́ \lambda \imath \theta o l$.

\section{Introduction}

Many aspects of the sedimentary origin of iron-rich rocks and soils, consisting mainly of hematite, an important indicator for exobiology, remain unresolved (Bekker et al., 2010; Bishop, 1998). Most prismatic or platy hematite in an iron-ore formation is the result of post depositional or diagenetically late upgrade processes; however, the $\mathrm{Fe}$ oxidation mechanisms, i.e. biological versus non-biological, currently are not determined with certainty (Ohmoto et al., 2006; Beukes and Gutzmer, 2008). Primary micron-sized hematite spheroids are scarce in the geological record, and they have only been reported from modern iron oxide deposits of the Red Sea (TaitelGoldman and Singer, 2002), and Archean banded iron formations (BIF) of the Hamersley Province, Australia (Ayres et al., 1972); these hematite spheroids have been interpreted as aqueous deposited low-temperature early diagenetic products (Bekker et al., 2010). Moreover, nanophase (nm-sized) grey spherulitic hematite, known to be formed by both biotic and abiotic aqueous-fluid processes on Earth, has been spectroscopically identified on the Martian surface, and raised the possibility of liquid water and biological activity on Mars (Bishop, 1998).

Here, we are undertaking a laboratory study of laminated iron oxide-bearing cement samples from a fossil-beach conglomeratic deposit, NW Milos Island, Greece. The conglomerate forms an interbed in Early Quaternary volcaniclastic sandstones/sandy tuffs which host the Cape Vani MnBa-Fe oxide deposit that is known as a distinct littoral to tidal-flat metallogenic environment related to the activity of ancient microbial mats and white smoker-type seafloor hydrothermal venting (Kilias, 2012). The scope of the paper is to document micron-sized spheroid hematite occurrences, and morphologic (i.e. fossil microbes, filaments, or biofilm) and chemical (i.e. organic) biomarkers, in an attempt to decipher the origin of hematite.

\section{Materials and Methods}

Polished sections of the Vani fossil-beach conglomeratic ferruginous cement is prepared for study. These were sputtered with either carbon or gold for avoiding charging in insulating areas, for EPA and ToF-SIMS analysis. Especially for the ToF-SIMS analysis, a smaller sample was cut to allow its easy insertion into the sample holder and the ultra-high vacuum chamber. This was also required to allow quick vacuum generation, since the sample contains a high number of pores. Optical, scanning electron microscopy and analysis (SEM/EDS) (National and Kaposdistrian University of Athens and National Technical University of Athens), micro-Raman (National Technical University of Athens) and Time-of-Flight mass spectrometry (University of Manchester) techniques were used to investigate the ferruginous cement. Reflected optical 
microscopy and imaging was performed with a Carl Zeiss Axioskop 40 microscope at various magnifications. Scanning electron microscopy and electron probe analysis were performed on a Jeol 6380LV electron microscope. On this instrument, a liquid nitrogen cooled Energy Dispersive Spectrometer (EDS) from Oxford Systems is installed. Acquisition is controlled through the INCA software. To achieve high-resolution secondary electron images and backscattered electron images, the acceleration voltage was set to $30 \mathrm{kV}$ and the smallest slit size (1) available was used. Chemical analysis was performed at $20 \mathrm{kV}$ and with a beam current on the sample of about $1 \mathrm{nA}$. Raman spectra were acquired with a confocal Renishaw Ramascope RM1000 Raman micro-spectrometer, attached to a Leica DMLM optical microscope. A $632.8 \mathrm{~nm}$ He-Ne laser is probed on the sample, on a spot size of less than $1.5 \mu \mathrm{m}$ when using the $\times 100$ objective lens and with energy, at the spot, of less than $5 \mathrm{~mW}$. Rayleigh scattering is reduced by an edge filter whose cut-off is at about $180 \mathrm{~cm}^{-1}$. The entrance slit to the spectrometer was set to $50 \mu \mathrm{m}$. The spectra acquisition system is composed of a grating of 1800 lines $/ \mathrm{mm}$ and a $576 \times 384$ pixel Peltier-cooled CCD camera. Spectra acquisition was made in continuous scanning mode. Final spectra are accumulated scans of a few individual spectra, each of 10 seconds integration time. The TOF-SIMS instrument used in this study is the "IDLE" instrument, and it is described in detail in Henkel et al. (2006). Mass-resolved spectra were acquired by sputtering with a pulsed gold $\left(197 \mathrm{Au}^{+}\right)$primary ion beam set at $25 \mathrm{kV}$ acceleration voltage. The beam size was about $1 \mu \mathrm{m}$, defining the spatial resolution of the acquired ion maps. The ion map manipulation and handling software is the "spaceTOF" (Chatzitheodoridis et al., 2005). The surface of the sample was always thoroughly cleaned prior to analysis by sputtering with a direct current ion beam in scanning mode. Positive and negative secondary ion spectra were acquired using both low mass and high mass resolution (about 500 and 2500, respectively).

\section{Results}

\subsection{Morphologic and Mineralogical Biosignatures}

The main volume of the sample is a ferruginous deposit, which glues together various detrital crystals, and partly fossilising biological material (cyanobacterial cells and their EPS). The detrital crystals are various common minerals, such as feldspar, Ti-magnetite, zircon and manganese minerals. Optical and scanning electron microscope (SEM) investigation of the ferruginous cement has revealed that it occurs as finely (micrometre scale) laminated colloform or botryoidal structures that bear morphological similarities to microstromatolites (e.g. Allwood et al., 2006; Lazăr et al., 2012) (Figure 1). The microstromatolites consist mainly of a remarkable cyclic repetition of growth laminae consisting of chainlike concentrations of spheroidal/coccoidal structures of variable size, aligned parallel to the microlamination, enclosed in a gel-like mucoid film (Figures 1, 3). Oncoidal microstromatolites also occur, forming the cortices of rounded and bulbous oncoid-like structures, and are developed as closely packed build-ups surrounded by colloform or botryoidal microstromatolites; they range in size from 50 to $200 \mu \mathrm{m}$ and have a globular to elongated/flattened shape. In general, microlamination is a result of a combination of differential porosity, and weathering of the film material, as well as size variability of the spheroids/coccoids. The laminae are composed mainly of hematite and organics (see below). Detrital silicates (adularia, chlorite) represent a minor component of some laminae and when present, are mainly found in specific detrital layers. This indicates that stromatolite growth was mainly controlled by in situ precipitation.

Hematite in the microstromatolites was identified by Raman spectroscopy (Figure 2). This hematite compares very well to a metamorphic hematite used as reference and to hematite measured by Shim and Duffy (2001), with only minor offsets of the peak positions. One exception is a wide peak centred at $660.6 \mathrm{~cm}^{-1}$, which is normally a forbidden band for Raman but IR-active. This peak has been interpreted to represent either surface resonance of incomplete symmetry of hematite, due to stress-induced defects or the first overtone of the $1318.3 \mathrm{~cm}^{-1}$ peak (Shim and Duffy, 2001), or, due to impurities (Zoppi et al., 2005). Partial transformation to magnetite due to 
the effect of the laser beam has been also suggested (Ulubey et al., 2008; Bouchard and Smith, 2003), however, it seems not applicable here due to the very low energy of the beam used, and its presence to all performed analyses irrespectively of conditions, except for our standard hematite spectrum. A peak at $658 \mathrm{~cm}^{-1}$ is reported by Bikiaris et al. (1999) and is attributed to the Al-O-Si bond of clays, e.g. kaolinite. Vani hematite samples do contain traces of clay, however, this peak in our spectra, is interpreted as a result of disorder (Shim and Duffy, 2001) due to its high intensity.

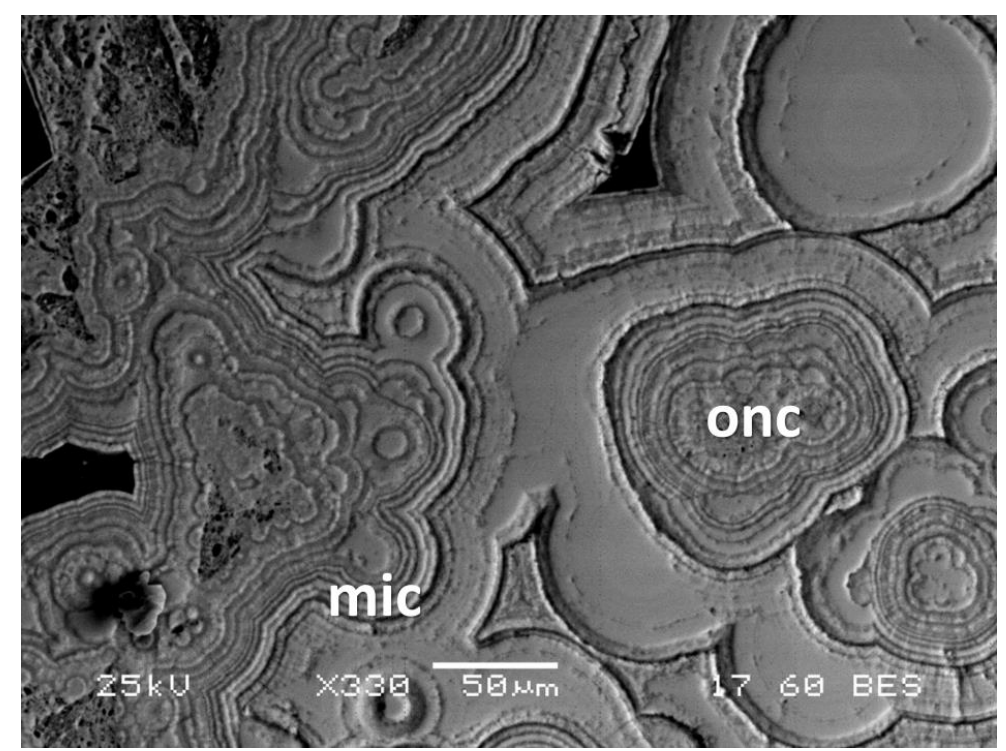

Figure 1 - ackscattered electron (BSE) image of micrometre-scale ferruginous microstromatolites (mic) and oncoidal microstromatolites (onc) cementing a fossil-beach conglomerate, NW Milos Island, Greece.

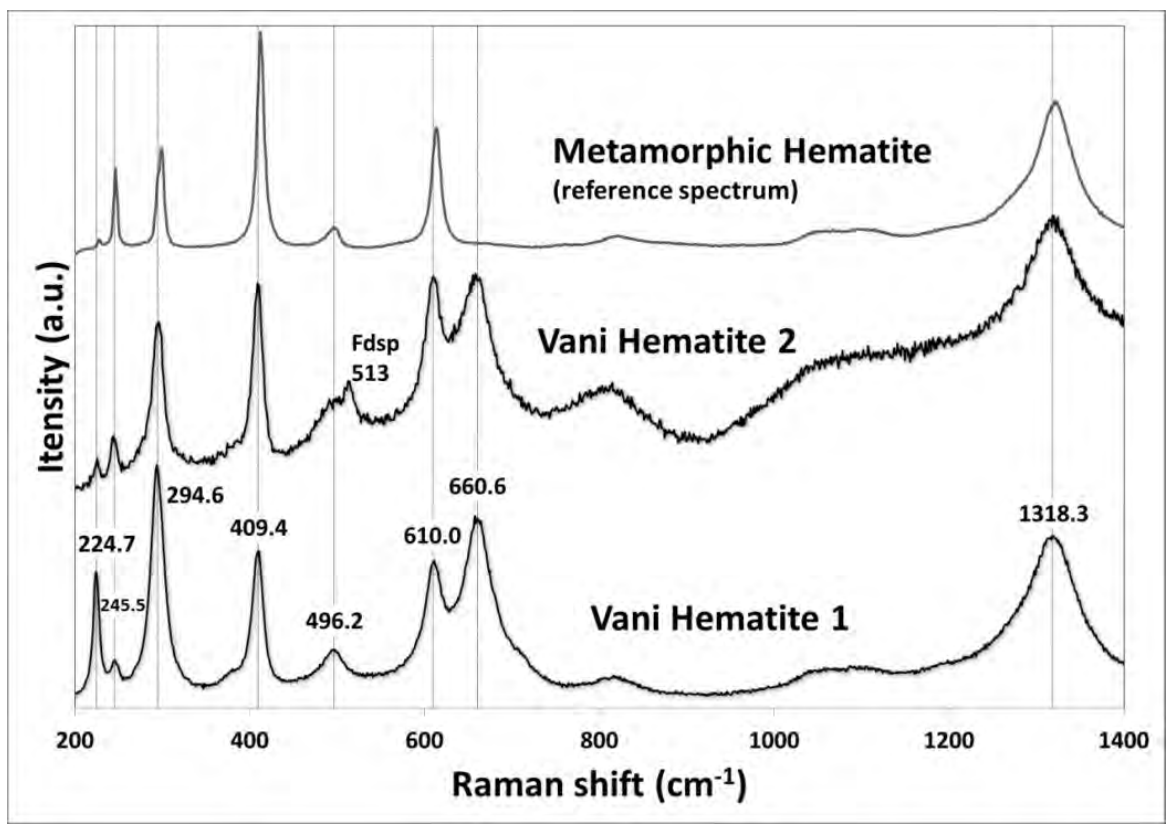

Figure 2 - Raman spectra of Vani hematite (spectra 1 and 2) compared to a reference highly ordered hematite of metamorphic origin. The Vani hematite 2 spectrum shows additionally a feldspar peak (Fdsp; $\left.513 \mathrm{~cm}^{-1}\right)$. 


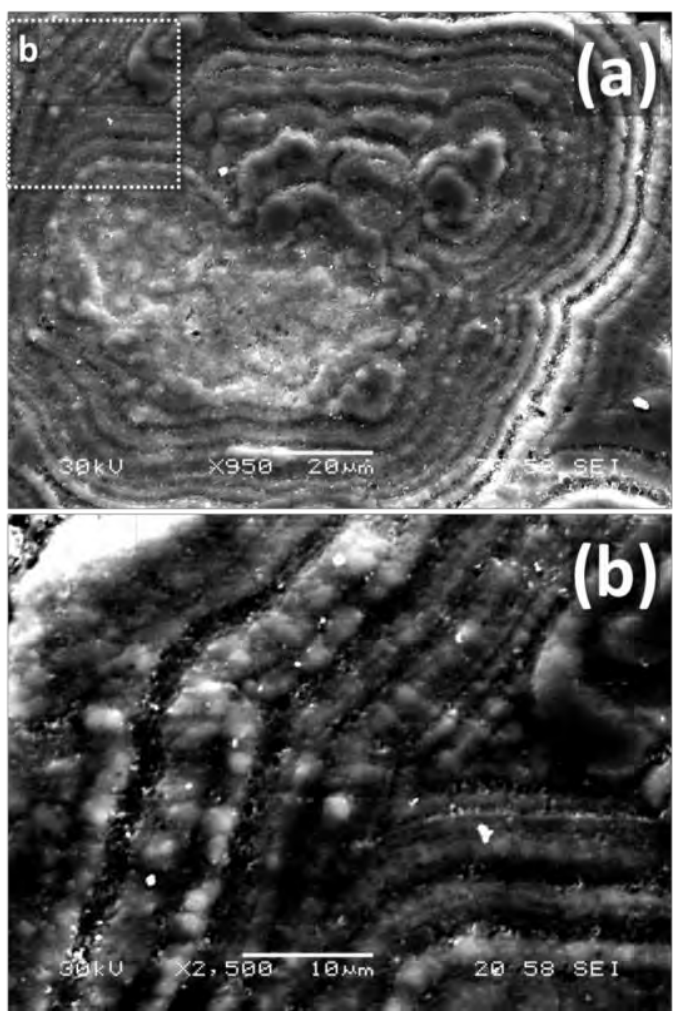

Figure 3 - Sequence of progressively higher magnification of backscattered electron images o f chain like concentrations of spherical/coccoidal hematite structures with variable size (b) di stributed along microstromatolitic laminae (a) composed of bands ranging from 2 to $5 \mu \mathrm{m}$ thi ckness of mainly hematite and organics, plus Mn, Na, Ca, and lesser K (see below).

\subsection{Molecular Biomarkers}

In order to set the inorganic frame on which organics sit, firstly a set of ToF-SIMS ion maps of the major elements is given (Figure 4), together with the total ion image which is the sum for all counts measured in each pixel. Iron ion map coincides with the stromatolitic texture. Dark areas on Figure 4 indicate voids or silicate mineral composition, i.e. such as feldspars, or chlorite. The results obtained by TOF-SIMS demonstrate the presence of $\mathrm{Mn}, \mathrm{Mg}, \mathrm{Si}, \mathrm{Na}, \mathrm{Ca}, \mathrm{Al}$ and lesser $\mathrm{K}$, within the microstromatolitic lamination (Figure 4). This elemental distribution may indicate detrital silicate minerals along the specific lamina, most probably fine distributions of clays, micas and feldspars. Especially on the bright spots that concentrate on the bottom-right of the images, mainly feldspars are located, as evidenced also from electron probe investigations. This zone is also composed of more diffused $\mathrm{Mn}, \mathrm{Mg}, \mathrm{Na}$ and $\mathrm{Ca}$. Probably these elements are present in the matrix of hematite as well. The very limited occurrence of $\mathrm{K}$ in this layer compared to the rest of the area, together with the enrichment in $\mathrm{Na}$ is intriguing. This might be resolved if the molecular ion maps of hydrocarbons are considered, as shown on Figure 5.

Figure 5 demonstrates that the hematitic lamina already described is preferentially enriched in carbonaceous material in the form of hydrocarbon fragments. Hydrocarbon fragments with odd $\left(\mathrm{C}_{2 \mathrm{n}+1} \mathrm{H}_{\mathrm{x}}\right)$ and even $\left(\mathrm{C}_{2 \mathrm{n}} \mathrm{H}_{\mathrm{x}}\right)$ number of carbon atoms, as well as organic molecules containing oxygen, seem to be especially rich in this layer. Mono-carbonic chains $\left(C_{n}\right)$ show an even distribution coinciding with the iron-rich area. These chains probably have a different origin e.g. contamination. To investigate the distribution of hydrocarbons as well, a detailed analysis of the mass spectrum was performed and the intensities of the peaks were measured. The result is shown in Figure 6, which demonstrates a systematic abundance of hydrocarbon fragments.

XLVII. No $2-838$ 


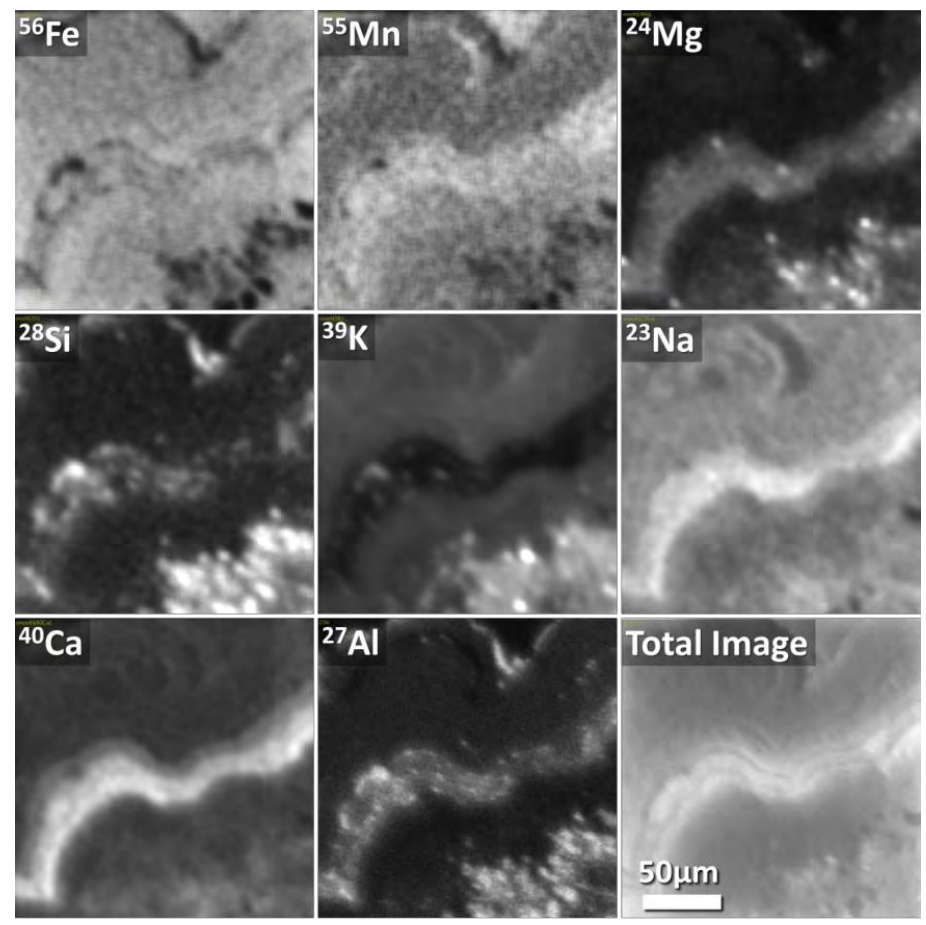

Figure 4 - ToF-SIMS ion maps of major elements. "Total Image" is the total ion image, which is composed of all ions of the spectrum acquired from each pixel.
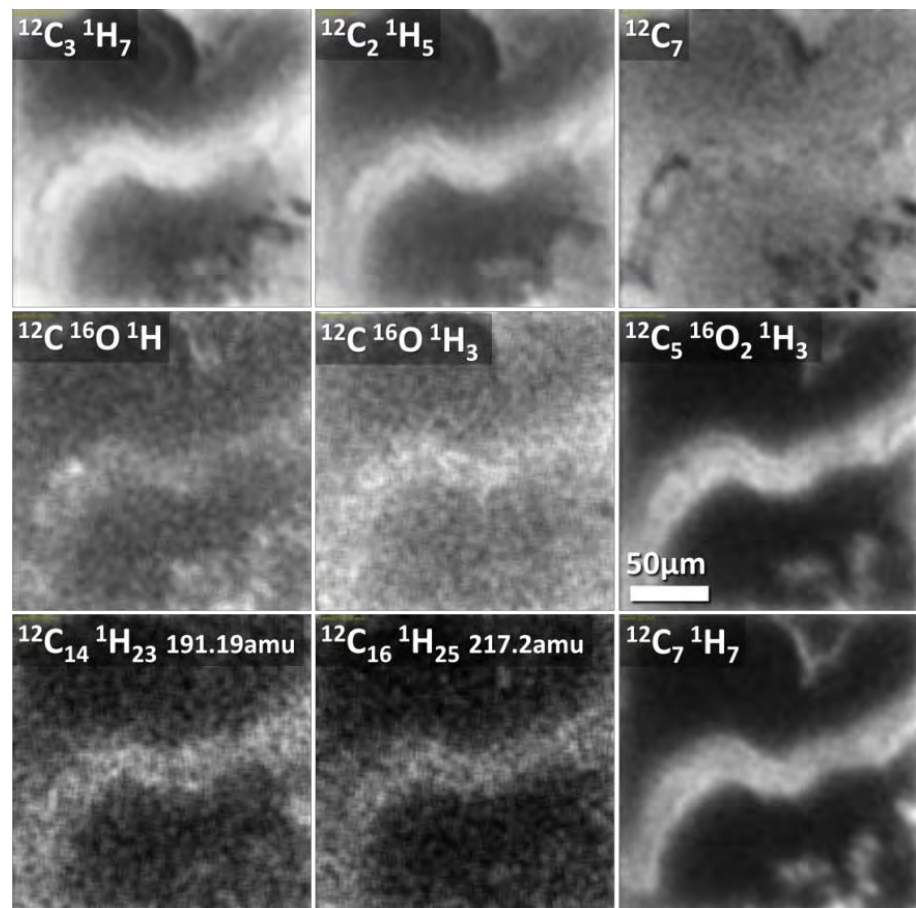

Figure 5 - ToF-SIMS molecular ion maps of the carbonaceous matter in hematite lamina of the Vani microstromatolites. Note the good correspondence between hematitic coccoidal microfossils and the distribution of globular carbonaceous matter, i.e. $\mathrm{C}_{5} \mathrm{O}_{2} \mathrm{H}_{3}, \mathrm{C}_{7} \mathrm{H}_{7}$, and $\mathrm{C}_{3} \mathrm{H}_{7}$.

$\underline{\text { XLVII, No } 2-839}$ 


\section{Discussion-Conclusions}

The biogenicity and syngenicity of the morphological and chemical signatures were evaluated according to a series of published criteria (Westall et al., 2011; Schopf et al., 2010). The Vani hematite-rich conglomeratic cement shows typical features of microstromatolitic microbialites, i.e. laminated organosedimentary deposits resulting from benthic microbial community trapping and binding clastic sediment particles and/or inducing mineral precipitation (Burne and Moore, 1987; Burkhalter, 1995). The microbialites exhibit two main morphological fabrics: (i) hematitic microstromatolites (Burkhalter, 1995), and (ii) hematitic oncoidal microstromatolites (Cavalazzi et al., 2007) (Figure 1). The Vani Fe-microstromatolites show features extremely similar to typical biogenic stromatolites, such as non-isopachous micrometer-scale alternations of smooth to wrinkly growth laminae, linked domical pseudocolumns with continuous bridging laminae between them, hemispherical to bulbous 3-D laminae shape, and thickening of laminae over the crests of the domes (Allwood et al., 2006; Rossi et al., 2006)(Figures 1, 3). Hematitic oncoidal microstromatolites form the cortices of rounded and bulbous, oncoid-like structures and occur as closely packed build-ups surrounded by colloform banded microstromatolites; they range in size from 50 to $200 \mu \mathrm{m}$ and have a globular to elongated/flattened shape. The strongest evidence that these structures are stromatolitic microbialites, however, is the outstanding profusion of fossil microbes in the form of hematitic spheroids, in the stromatolitic laminae. The hematitic spheroids have morphological characteristics consistent with colonies of coccoidal fossil microbial cells (Schopf et al., 2010), and the polymer film maintains morphological details identical to fossil extracellular polymeric substances (EPS) produced by the cells (Westall et al., 2000). This, combined with the alignment of the coccoidal fossil microbes parallel to the convex outward microlamination, offer strong evidence that microbes were active and not fortuitous in the development of such microstructures (Rossi et al., 2006).

Carbonaceous material, i.e. odd and even chained $\mathrm{C}_{\mathrm{x}}-\mathrm{H}_{\mathrm{y}}$ ionic molecules, $\mathrm{C}_{\mathrm{x}}-\mathrm{O}_{\mathrm{y}}-\mathrm{H}_{\mathrm{z}}$ molecules and mono-carbonic chains $\mathrm{C}_{\mathrm{x}}$, was identified in the hematite laminae using TOF-SIMS in a highly systematic abundance (Figure 6). Carbonaceous material occurs as micrometer-sized heterogeneously distributed chain-like globular clusters, as well as diffuse film-like material that coats both the hematite microfossils and their substrate, and it is exclusively associated with the hematite laminae. Moreover, according to Siljeström et al. (2010) hopanes and steranes constitute organic lipid biomarkers, indicative of cyanobacteria. Their diagnostic molecular ions are at 191.19amu for hopanes and 217.2amu for steranes. Both peaks exist in the spectra of the studied section of hematite and they follow the same pattern with the rest of the organic fragments (Figure 6). Therefore, it can be inferred that the carbonaceous material is indicative of the existence of biological material trapped in and/or with hematite.

According to its organic nature and in conjunction with the biomorphological evidence presented, the organic-rich hematite spheroidal and filmy material is thus interpreted as Fe- bio-mineralised fossil bacterial cells and associated fossil EPS, likely produced by iron-oxidising micro-organisms (Westall et al., 2000; Heim at al., 2012). Along with the presence of Fe, local selective enrichments of microstromatolitic laminae with inorganic bio-essential elements such as $\mathrm{Mn}, \mathrm{Na}$, $\mathrm{Ca}, \pm \mathrm{K}$ detected by ToF-SIMS, further support microbial mediated reactions. The combined detection of morphological, chemical and molecular ion biomarkers in the Cape Vani hematitic microstromatolites and oncolite-like structures clearly supports microbial mediation for their formation, and indicates that this microlamination may be used as a biosignature for Fe-rich biomats on Earth and for their detection in extraterrestrial materials. Moreover, the Cape Vani microstromatolites may contribute to growing our understanding of the function of microorganisms in the genesis of modern and ancient Fe and associated Mn deposits. 


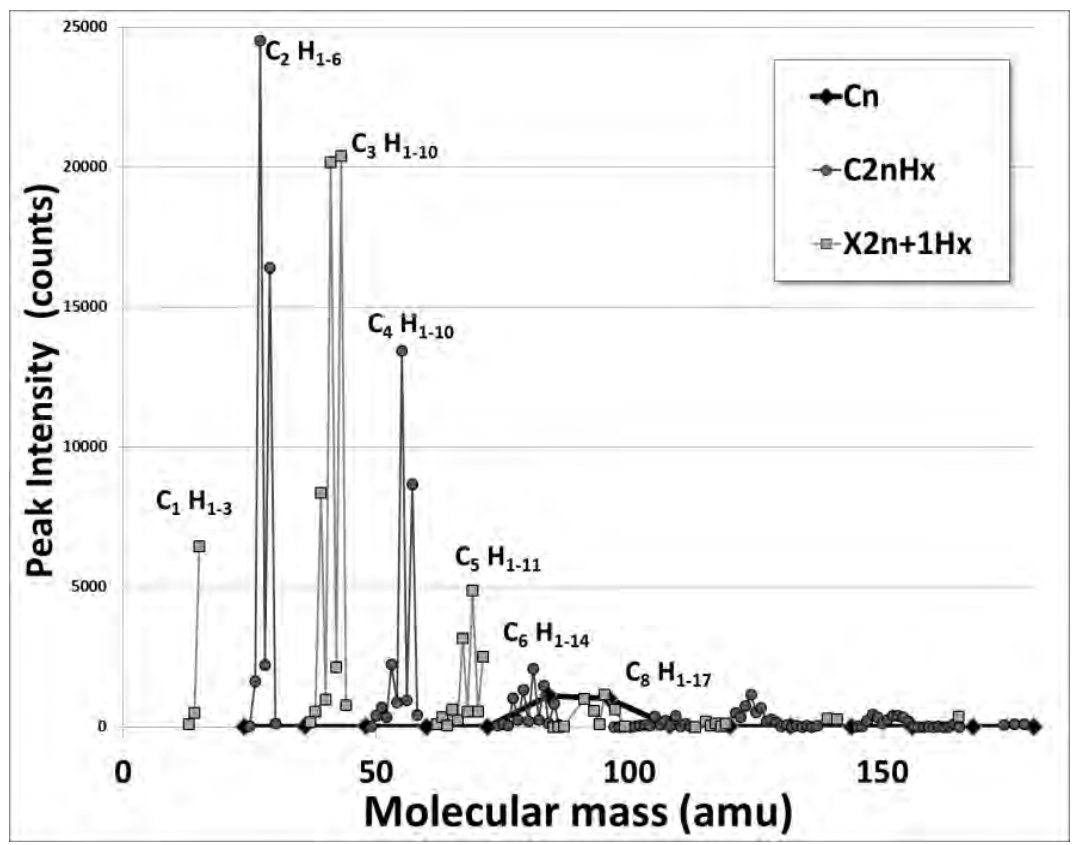

Figure 6 - Distribution patterns of mono-carbonic chains $\left(C_{n}\right)$, and hydrocarbon fragments with even $\left(\mathrm{C}_{2 n} \mathrm{H}_{\mathbf{x}}\right)$ and odd $\left(\mathrm{C}_{2 n+1} \mathrm{H}_{\mathbf{x}}\right)$ number of carbon atoms.

\section{Acknowledgments}

Funding by the Special Account for Research Grants of the National and Kapodistrian University of Athens to SPK is thankfully acknowledged.

\section{References}

Allwood A.C., Walter M.R., Kamber B.S., Marshall C.P. and Burch I.W. 2006. Stromatolite reef from the Early Archaean era of Australia, Nature, 441 (7094), 714-718.

Ayres D.E. 1972. Genesis of iron-bearing minerals in banded iron formation mesobands in the Dales Gorge Member, Hamersley Group, Western Australia, Economic Geology, 67, 1214-1233.

Bekker A., Slack J.F., Planavsky N., Krapež B., Hofmann A., Konhauser K.O. and Rouxel O.J. 2010. Iron formation: the sedimentary product of a complex interplay among mantle, tectonic, oceanic, and biospheric processes, Economic Geology, 105, 467-508.

Beukes N.J., and Gutzmer J. 2008. Origin and paleoenvironmental significance of major iron formations at the Archean-Paleoproterozoic boundary, Reviews in Econ. Geol., 15, 5-47.

Bikiaris D., Sister Daniilia, Sotiropoulou S., Katsimbiri O., Pavlidou E., Moutsatsou A.P. and Chryssoulakis Y. 1999. Ochre-differentiation through micro-Raman and micro-FTIR spectroscopies: application on wall paintings at Meteora and Mount Athos, Greece, Spectrochimica Acta, 56, 3-18.

Bishop J.L. 1998. Biogenic catalysis of soil formation on Mars? Orig. Life Evol. Biosph., 28(4-6), 449-459.

Bouchard M. and Smith D.C. 2003. Catalogue of 45 reference Raman spectra of minerals concerning research in art history or archaeology, especially on corroded metals and coloured glass, Spectrochimica Acta, 59, 2247-2266.

Burkhalter R.M. 1995. Ooidal ironstones and ferruginous microbialites: origin and relation to sequence stratigraphy (Aalenian and Bajocian, Swiss Jura Mountains), Sedimentology, 42, 57-74. 
Burne R.V. and Moore, L.S. 1987. Microbialites: organosedimentary deposits of benthic microbial communities, Palaios, 2, 241-254.

Cavalazzi B., Barbieri R. and Ori G.G. 2007. Chemosynthetic microbialites in the Devonian carbonate mounds of Hamar Laghdad (Anti-Atlas, Morocco), Sedimentary Geology, 200, 73-88.

Chatzitheodoridis, E., Lyon I.C. and Vgenopoulos A. 2005. Interactive geochemistry in the microand submicron scale: a visual software tool for ion map extraction, manipulation and analysis from TOF-SIMS spectra. In IMA05: The 4th International Conference on Instrumental Methods of Analysis, Modern Trends and Applications, Iraklion, Crete, Greece, 2-6 October 2005.

Heim C., Lausmaa J., Sjövall P., Toporski J., Dieing T., Simon K., Hansen B.T., Kronz A., Arp G., Reitner J. and Thiel V. 2012. Geobiology, 10, 280-297.

Henkel T., Tizard J., Blagburn D., Lyon I. 2006. Interstellar dust laser explorer (IDLE): A new instrument for submicron analyses of stardust-quantification of laser SNMS. Applied Surface Science, 252, 7117-7119.

Kilias S.P. 2012. Microbial-mat related structures in the Quaternary Cape Vani manganese oxide(barite) deposit, NW Milos island-Greece, in Noffke N., and Chafetz H., (Eds.), Microbial Mats in Siliciclastic Depositional Systems Through Time, SEPM (Society for Sedimentary Geology) Special Publication, 101, 97-100.

Lazăr I., Grădinaru M. and Petrescu L. 2013. Ferruginous microstromatolites related to Middle Jurassic condensed sequences and hardgrounds (Bucegi Mountains, Southern Carpathians, Romania). Facies, 59, 359-390.

Ohmoto H., Watanabe Y., Yamaguchi K.E., Naraoka H., Haruna M., Kakegawa T., Hayashi K. and Kato Y. 2006. Chemical and biological evolution of early Earth: Constraints from banded iron formations, Geological Society of America Memoir, 198, 291-331.

Rossi C., Lozano R.P., Isanta N. and Hellstrom J. 2006. Manganese stromatolites in caves: El Soplao (Cantabria, Spain), Geology, 38, 1119-1122.

Schopf W.J., Kudryavtsev A.B., Sugitani K. and Walter M.R. 2010. Precambrian microbe-like pseudofossils: A promising solution to the problem. Precambrian Research, 179, 191-205.

Shim S.-H. and Duffy T. S. 2001. Raman spectroscopy of $\mathrm{Fe}_{2} \mathrm{O}_{3}$ to $62 \mathrm{GPa}$, American Mineralogist, 87, 318-326.

Siljeström S., Lausmaa J., Sjövall P., Broman, C., Thiel V. and Hode T. 2010. Analyses of hopanes and steranes in single oil-bearing fluid inclusions using time-of-flight secondary ion mass spectrometry (ToF-SIMS), Geobiology, 8, 37-44.

Taitel-Goldman N. and Singer A. 2002. Metastable Si-Fe phases in hydrothermal sediments of Atlantis II Deep, Red Sea, Clay Minerals, 37, 235-248.

Ulubey A., Fazlioglu I., Erdogu B. 2008. Pigment identification in Hellenistic ceramics from the Tuz Gölü region of central Anatolia by confocal Raman spectroscopy, Ceramics, 52, 201 204.

Westall F., Foucher F., Cavalazzi B., De Vries S.T., Nijman W., Pearson V., Watson J., Verchovsky A., Wright I., Rouzaud J-N., Marchesini D., and Anne S. 2011. Volcaniclastic habitats for early life on Earth and Mars: A case study from $\sim 3.5$ Ga-old rocks from the Pilbara, Australia, Planetary and Space Science, 59, 1093-1106.

Westall F., Steele A., Toporski J., Walsh M., Allen C., Guidry S., McKay D., Gibson E. and Chafetz H. 2000. Polymeric substances and biofilms as biomarkers in terrestrial materials: Implications for extraterrestrial samples, J. Geophys. Res., 105(E10), 24511-24527, doi:10.1029/2000JE001250.

Zoppi A., Lofrumento C., Castellucci E.M., Migliorini M.G. 2005. The Raman spectrum of Hematite: possible indicator for a compositional or firing distinction among Terra Sigillata wares, Annali di Chimica, 95, 239-246. 